\title{
Fluid institutional logics in digital journalism
}

Lischka, Juliane A

\begin{abstract}
The negotiation of competing institutional logics is relevant for organisations active in multi-institutional domains. News organisations are active in the domains of democracy and business, and, through digitisation, they are active in the digital technology domain. This article describes how journalism negotiates competing logics of these domains, i.e. professional, market, managerial, and technology (tech) logics. Analysing $n=744$ individual NiemanLab Predictions for Journalism from 2014 to 2019, findings indicate that journalism aggregates and integrates competing logics in a fluid way, keeping synergies across logics and plurality of logics high. The field of journalism is shaped by the competition of four logics: While tech logics induce changes in professional, market, and managerial logics, professional logics remain the dominant moral compass for journalists.
\end{abstract}

DOI: https://doi.org/10.1080/16522354.2019.1699764

Posted at the Zurich Open Repository and Archive, University of Zurich

ZORA URL: https://doi.org/10.5167/uzh-182044

Journal Article

Accepted Version

Originally published at:

Lischka, Juliane A (2020). Fluid institutional logics in digital journalism. Journal of Media Business Studies, 17(2):113-131.

DOI: https://doi.org/10.1080/16522354.2019.1699764 


\title{
Fluid Institutional Logics in Digital Journalism
}

Juliane A. Lischka

Department of Communication and Media Research

University of Zurich

Andreasstrasse 15

8050 Zurich

Switzerland

j.lischka@ikmz.uzh.ch

\begin{abstract}
The negotiation of competing institutional logics is relevant for organizations active in multiinstitutional domains. News organizations are active in the domains of democracy and business, and, through digitization, they are active in the digital technology domain. This article describes how journalism negotiates professional, market, managerial, and technology (tech) logics. Analyzing $\mathrm{n}=744$ individual NiemanLab Predictions for Journalism from 2014 to 2019, findings indicate that journalism aggregates and integrates competing logics, keeping synergies across logics and plurality of logics high. The field of journalism is shaped by the competition of four logics. While tech logics induce changes in professional, market, and managerial logics, professional logics remain the dominant moral compass for the negotiation of competing logics.
\end{abstract}

Keywords: digital journalism, digital technology, institutional logics, institutionalism, organizational change, technology management 


\section{Introduction}

Changing environments often expose companies to new institutional logics that potentially contradict the logics a company adhered to in the past, introducing institutional complexity (Greenwood, Raynard, Kodeih, Micelotta, \& Lounsbury, 2011). Thereby, a company's old institutional logics shape the company's response to new logics (Waeger \& Weber, 2019). This article proposes that the socio-technological change in the digital age has exposed news organizations, and journalism altogether, to a novel state of institutional complexity, giving rise to conflict and demanding negotiation. The article conceptualizes the digitization of journalism as a response to institutional complexity.-While journalism is experienced in negotiating competing institutional logics, usually following business goals and democratic values (Hamilton, 2004; Schudson, 1989), the digital age has introduced profound social change regarding audience behavior (Tewksbury, 2005; Webster \& Ksiazek, 2012) as well as technological change often described as disruptive to news organizations (Küng, 2015; Picard, 2003). Thus, journalism's institutional environment has become more complex, and journalism adapted towards a "digital journalism".

To develop my claims, first, I theorize news companies as hybrid organizations (Haigh \& Hoffman, 2012) that manage multiple institutional domains (Pratt \& Foreman, 2000). Second, a review of recent research into digital journalism suggests an increase of technological logics at the expense of "doing it for the public" (Deuze, 2005, p. 447). Third, an analysis of micro-level narrations about the future of journalism using the NiemanLab Predictions for Journalism sheds light on journalism's negotiation of competing logics.

The purpose of this article is to contribute to the understanding of the negotiation of competing logics and the relation between digital technology and journalism. This article applies the concept of competing institutional logics to news companies and, following the 
call of Peters and Carlson $(2018,4)$, offers a meta-reflection on institutional logics in journalism to understand "why and how the field is shaped as it is."

\section{Literature Review}

\section{Institutional logics}

Institutional logics are initially conceptualized as "supraorganizational patterns of human activity by which individuals and organizations produce and reproduce their material subsistence and organize time and space" (Friedland \& Alford, 1991, p. 243). These "ways of ordering reality" (Friedland \& Alford, 1991, p. 243) describe practices and beliefs that are appropriate in certain institutional domains, such as the bureaucratic state, democracy, capitalist market, family, and religion. Each institutional domain has a central logic that guides its organizing principles and provides actors with vocabularies of motive and identity. Institutional logics are supraorganizational cognitive and behavioral patterns that determine the relation between organizations, individuals, and society within each domain. Institutional logics therefore shape and constrain behavior by specifying which actions and interpretations are appropriate and should be pursued within a given domain (Thornton, Ocasio, \& Lounsbury, 2012).

Alvesson, Hallett, and Spicer $(2019,123)$ criticize the overpacked definition of institutional logics because it regards everything as an institution, "from the handshake to the corporation [...] to a procedure for accountability." This study conceptualizes institutional logics somewhat parsimoniously as socially constructed, normative guides for the interpretation, identity and behavior of actors within a certain institutional domain. Thereby, institutional logics vary depending on the dominant institutional domain an actor is situated in and are reflected in her or his practices and vocabularies. 


\section{Competing institutional logics}

In multi-domain constellations, for instance a combination of capitalist and democratic domains such as in journalism, institutional logics can be contradictive. Organizations in a capitalist-democratic constellation are embedded in "competing social welfare and commercial logics" (Pache \& Santos, 2013, p. 972) so they find themselves falling "between mission and revenue" (Ponte, Pesci, \& Camussone, 2017, p. 196). McManus (1992a, p. 205) argues regarding the disparity between mission and revenue in journalism that news has to be regarded as commodity by commercial companies but as "something more than a commodity" when it comes to external effects of news for democratic societies. To produce more than a commodity, journalists work for the public, often described as taking a watchdog role and representing a fourth estate (e.g., Deuze, 2005). According to Brès, Raufflet, and Boghossian (2018, p. 376), news organizations thus represent hybrid organizations as they face "incompatible, possibly even oppositional, institutional logics."

The literature on hybrid organizations often focuses on a duality of domains. However, companies negotiate logics from multi-faceted domains. Nicolini et al. (2016) evaluate how professional, market, managerial, and regulative logics are negotiated in organizational decisions. For instance, scientific quality standards should determine pharmaceutical products according to professional logics, customer preferences should determine products from a market logics perspective, and the management or the state decide on products to be sold from a managerial and regulative logics perspective, respectively (Nicolini et al., 2016).

Moreover, in the digital age, digital technology logics evolve as an additional institutional domain. The prevalent logic of the digital technology domain involves the belief in the ubiquitous capacity of technology. Healey and Woods (2017) describe techno-utopian views as central part of the Silicon Valley ideology. Russell (2017) argues that such logics 
build an institutional force embracing the belief that every problem can be solved with digital technology and that technology therefore serves society. As a result, humans "naively believe that for most personal and social needs there must be largely technological solutions" (Schultze, 2004, p. 19). This indicates that technology logics determine customer demands, i.e., market logics. Thus, companies that apply digital technology for their products and services expose themselves with such logics as well.

In such multi-domain settings, organizations must negotiate conflicting logics in a way individuals within the organization can identify with and behave upon. The next section describes negotiation strategies for incompatible logics.

\section{Negotiating competing institutional logics}

Dealing with opposing institutional logics can cause intense internal conflict (Brès et al., 2018). Pratt and Foreman (2000) classify four major negotiation strategies for managing competing institutional logics. These strategies vary regarding the plurality of and synergy between competing logics. First, companies can compartmentalize logics so that each logic maintains within a certain area, but no synergies exist between them. Compartmentalization is reasonable when multiple logics are frequently in conflict and too valuable to be reduced or removed. In journalism, the segregation between the advertising department and newsroom represents compartmentalization. In fact, any synergy between both is regarded problematical for the fourth estate role. Second, companies can delete competing logics, for instance, when one logic is negatively connotated or peripheral to the main mission. Deletion is easy to implement if the logic is associated with a certain compartment of the organization, which can be "chopped off" (Pratt \& Foreman, 2000, p. 29). For instance, news organizations that are solely funded by their audiences or subsidies may be able to chop off advertising market logics. Third, multiple logics may be fused to a complete new one through 
creating synergies between them. This strategy may occur for instance after a merger of two companies when logics hybridize (Pratt \& Foreman, 2000). In digital journalism, audience orientation has become a novel value for journalists' professional identity (Lischka, 2018; Møller Hartley, 2013), representing a fusion between professional and market logics. Fourth, competing logics can be aggregated through linking them to each other. In this scenario, relationships between competing logics are identified and synergies exploited. This can lead to a hierarchy of logics in a way that organizations manage competing logics via paying sequential attention or activating the logic that is most salient in an immediate situation. Also, a meta-identity can be developed through creating justifications and myths about inconsistencies of competing logics (Pratt \& Foreman, 2000).

The following section reviews the state of recent research in digital journalism to illustrate how professional, market, managerial (Nicolini et al., 2016), and technology logics (Russell, 2017) are negotiated.

\section{Competing institutional logics in journalism}

Professional logics. Research about professional logics is a major theme in journalism studies. Professional role conceptions of journalists fluctuate between being a neutral gatekeeper selecting important information for the public to an interpreter of publicly relevant events and activist advocate of ideas who not only sets the public agenda but seeks for social impact (see Hanitzsch \& Vos, 2017 for an overview). While the former is related to norms such as objectivity, the latter emphasizes the importance of opinion. A central normative ideal of journalism includes being a watchdog of societal fields such as politics, business, and the economy with the goal to enhancing society. Based on the watchdog ideal, journalism is understood as fourth estate besides legislative, judiciary, and executive. Historically, the liberal press gained political party independence by being profitable and 
thereby was able to act in the role of the fourth estate (Schultz, 1998). Thus, the aspect of being profitable is historically coupled to normative professional standards. Therefore, market orientation is identified as a dimension of professional role conceptions (Hanitzsch, 2007). Moreover, a maxim of publishers is that good journalism and good business are strongly related (McManus, 1992b), indicating that normative professional logics are negotiated with market logics (Hanitzsch \& Vos, 2017).

Market logics. Market logics comprise the orientation towards the advertiser and audience markets to produce news. When considering market logics, news is regarded a commodity that is produced and sold to maximize profit, specifically when commercially produced. News is usually sold to advertisers and audiences (in exchange for money and/or attention) and thus serves two markets. Thereby, the quality is central for its success on both markets, i.e., that news is accurate and fair, provide enough context for comprehension, and relevant for a certain community (McManus, 1992b), indicating that professional and market logics are related. However, news is primarily targeted to communities that are relevant for advertisers, leading to insufficient supply of not commodifiable minorities. McManus (1992b) argues that the similarity of market and professional logics is the principle of audience size maximization, while professional logics are not concerned with costs of discovering and covering news as well as advertiser maximization. Thus, pursuing market logics of commercialization over other logics leads to a loss of content quality and potentially to the "breakdown of church and state", i.e., the segregation between the editorial and business side of the news company (e.g., McChesney, 2000; McManus, 2009; Picard, 2010).

Managerial logics. Managerial logics address the functional structure, process, and operations of an organization and aim at efficiency and productivity (Raviola \& Hartmann, 2015). Managerial tasks for news companies include the development of leadership and 
business competence in organizations as well as evolving a view of individuals as entrepreneurs (Achtenhagen, 2015; Achtenhagen \& Raviola, 2009; Andersson \& Wiik, 2013). In the digital age, legacy news organizations have needed to renew their competencies (Lischka, 2019b). However, inertia and a residual fit of the print technology often hindered particularly legacy news organizations to implement digital technologies, although an awareness about this necessity existed (Dennis, Warley, \& Sheridan, 2006; Gilbert, 2005, 2006). Therefore, a major managerial task represents overcoming the rigidity to change, which is an issue for editorial staff regarding new working procedures and a change in culture (Ekdale, Singer, Tully, \& Harmsen, 2015; Jenkins, 2008; Ryfe, 2009; Singer, 2003). Thereby, managerial logics are negotiated with professional logics, while this negotiation is induced by technological change.

Tech logics. Tech logics in journalism are related to digital technology used for the production and distribution of news. For instance, search engines recommend multiple versions of news about an event without providing an interpretative order, which is however central from a professional point of view (Carlson, 2016). Regarding social media, DeVito (2017) argues that Facebook's News Feed's algorithmic recommendations fundamentally differ from journalistic news factors, i.e., professional values. Whereas traditional news factors relate to deviance and social impact of a story, the News Feed algorithm merely considers personal significance. Since algorithmic recommender systems of digital platforms follow market logics, i.e., the commodification of user data (Wu, 2016; Zuboff, 2019), these market logics of digital platforms become action-guiding in journalism (Lischka, 2018). Besides logics induced through digital technologies' functionalities, the companies providing digital technology for news distribution are found to hold techno-utopian views such as technology's superior capacity to solve every social problem as well as views that 
are incompatible with news organizations' revenue models, i.e., that information should flow freely (Healey \& Woods, 2017; Russell, 2017), which are discursively put across and guide the conduct of digital platforms.

\section{Negotiating competing institutional logics in journalism}

Negotiating professional and market logics. Journalism has long been negotiating the two competing norms of acting in the public interest and often being a profit-oriented business (Burrowes, 2011; Hamilton, 2004), which manifests in content differences depending on the dominant logic per news outlet (Beam, 2003). News companies generally solve the competition of normative professional and market logics on the level of company structure. That is, news organizations differentiate departments to cope with competing journalistic-autonomous and market-oriented goals (Lowrey \& Erzikova, 2014), suggesting a compartmentalization strategy according to Pratt and Foreman (2000).

However, contemporarily, professional norms and market logics are increasingly integrated within newsrooms (Cornia, Sehl, \& Nielsen, 2018), suggesting an integration process (Pratt \& Foreman, 2000). Research shows indicators of integrating market logics into professional norms in a greater user-orientation in news making (Lischka, 2018; Wasike, 2013) and using audience metrics for understanding user behavior (Cherubini \& Nielsen, 2016; Tandoc \& Ferrucci, 2014; Zamith, 2018). Nelson and Tandoc Jr. (2018) demonstrate that journalists regard addressing a mass audience using audience analytics and providing mission-driven reporting as mutually exclusive. Similarly, Welbers, van Atteveldt, Kleinnijenhuis, Ruigrok, and Schaper (2016) report that journalists consider the use of audience metrics for news selection to be in conflict with their professional values. Still, audience engagement and outreach are found to be part of journalists' digital gatekeeping roles (Chua \& Westlund, 2019; Scacco, Curry, \& Stroud, 2015), which is related to 
functionalities of digital technology (Hanusch, 2017; Wallace, 2018). That is, market and professional logics form synergies against the background of the digitization of journalism.

Negotiating professional and tech logics. In the digital age, professional logics are determined by the operating modes of new digital technology that is used for the distribution of news. Deuze (2003) argues that professional roles of journalism changed in the digital age. Regarding online journalism, Deuze (2003) develops four professional types: Instrumental journalism seeks to serve specific audience needs, orientating journalism helps to make sense of the world through commentary and analysis, monitorial journalism offers information the public can connect to, and dialogical journalism amplifies the conversation within society. These professional roles result from the functionalities of digital technology for the production and distribution of news. The functionalities of digital technology transform professional logics of journalists, especially regarding achieving social impact. Social impact appears to be compatible with the logics of social media: Editors prefer to post such content on social media that affects as many users as possible and therefore maximizes engagement (Neuberger, Langenohl, \& Nuernbergk, 2014). Journalists who regularly use social media think that the traditional roles of journalism must be reconsidered in contrast to journalists using social media less often (Hedman \& Djerf-Pierre, 2013) and tend to regard being a mobilizer of the public and disseminator of news as more relevant than being an adversary of officials and interpreter of events (Willnat \& Weaver, 2018). This includes to "motivate people to get involved" or "let people express their view" (mobilizer) and to "get information to the public quickly" as well as "reach the widest audience possible" (disseminator) (Willnat \& Weaver, 2018, p. 903).

Moreover, online news start-ups are found to be pioneers in technology adoption (Carlson \& Usher, 2016; Nee Coates, 2013; Wagemans, Witschge, \& Harbers, 2018). Start- 
ups seek not only technological but an ideological innovation in journalism. Studying founding manifestos of news start-ups, Carlson and Usher (2016) report that start-ups highlight their innovation efforts and strive to erase boundaries between journalistic and technological identities. Technology is innovatively applied to create an improved user experience for news consumption, which start-ups emphasize as unique selling proposition. Moreover, Carlson and Usher (2016, p. 574) conclude that start-ups "draw on technological superiority" to differentiate from traditional news. Yet while putting technology into the center, start-ups also refer to traditional standards to claim legitimacy as a member in the field of journalism. Carlson and Usher (2016, p. 576) observe that

the visions expressed in [news start-ups'] manifestos do not disrupt underlying and long-held journalism ideals and traditional aspirations. Instead of attempting to supplant the journalistic field, they enshrine its existing aspirations and understandings by hoping to further journalism's goals with new types of products that will make journalism better for the public.

Similarly, Coates Nee (2014, p. 3) explain that small nonprofit news companies regard technology as central, however apply technology it in order to comply to the public interest principle: "journalists who lead these small firms view digital and social media as opportunities to revitalize public service reporting, re-create journalism practices online, and encourage consumer participation in the news-gathering process.” Wagemans et al. (2018, 1) describe this use of technology in the public interest as "social innovation" that integrates divergent norms. Wagemans et al. $(2018,1)$ conclude that journalists "marry different, commonly-deemed incompatible practices and values, thus challenging binary distinctions at the heart of conceptualisations of journalism," indicating multi-logic hybridization. That 
is, tech logics are fused with professional logics and form a novel state of tech-induced professional logics. The fusion of tech and professional logics is central to the professional identity of "news nerds", the technologists of newsrooms. The newsroom technologists are fourth-estate mission-driven and believe that problems of journalism can be solved through the application of digital technology (Kosterich, 2019).

Negotiating professional and managerial logics. The editor is traditionally the role in news organizations that combines professional and managerial logics. Editors lead a team, socialize journalists, know organizational goals, and decide what goes out as news. Being an editor demands switching between professional and managerial logics:

When they seek objective facts, they are clearly in the former camp; when they discipline a reporter for not doing so, they have a foot in each; and when they angle a story to conform to the news organisation's business or political agenda, they may be considered firmly in the second camp. (Duffy, 2019, p. 8)

Managerial editors regard an innovation culture within the newsroom as more relevant than journalists without managerial experience (Lischka, 2015). Besides the editor, managerial thinking becomes more relevant for all newsroom workers. During the digitization of newsrooms, journalists have experienced a process of organizational change. How managerial and professional logics are negotiated is revealed in that process of newsroom convergence, i.e., the integration of digital and traditional news making. While journalists agree that there is a need for change in news making when serving digital audiences as opposed to traditional audiences, cultural adoption to the digital environment is found to be tough and lengthy (Ekdale et al., 2015; Larrondo, Domingo, Erdal, Masip, \& 
van den Bulck, 2016; Ryfe, 2009). Changing news practices are accompanied by confusion, indignation, and resistance (Ekdale et al., 2015; Larrondo et al., 2016; Ryfe, 2009).

Going through this convergence process, journalists are expected to develop a sense of entrepreneurialism, suggesting that managerial logics are integrated into professional logics. Against the background of journalisms' revenue model crisis, entrepreneurialism is described to be vital for journalism's survival in a digital age (Vos \& Singer, 2016). Especially journalists who decide to start a news company find themselves in various managerial roles having to focus on investors, a business model, revenue streams, technical infrastructure, human resource management, and leadership, besides defining the journalistic stance of their outlet (Wagemans, Witschge, \& Deuze, 2016). Wagemans et al. (2016) case study of the successful French start-up Mediapart suggests that the founding editors apply a segregation strategy in the sense of Pratt and Foreman (2000), keeping all logics separate and activating the necessary role in the appropriate situation.

There are also indicators for an influence of professional logics towards managerial logics, indicating a higher hierarchy of professional logics. For instance, taking an activist role is appreciated by managers of strongly market-oriented news companies. In this manner, Tandoc and Foo (2017, p. 11) cite a BuzzFeed journalist with:

[BuzzFeed's senior management] do like stories that $[\ldots]$ get a lot of Facebook notifications. [But] if you made something happen, if the army withdrew a manual because of what you did, then you did a good job. [...] they are looking for old fashion impact. 
Such an impact focus has become a normative conception in journalism in the social media era (Bro, 2018; Wagemans et al., 2018). Thus, professional logics can match managerial logics.

Negotiating managerial and tech logics. The negotiation of managerial logics with tech logics appears rather conflict-free and manifests in the organizational structure of news companies, new job descriptions, and individual capacities of journalists. Legacy news organizations have a focus on digital technical expertise. Digital technology is expected to be part of the DNA of news organizations (Küng, 2017). This technology focus is connected to multiskilling requirements for journalists regarding the production and distribution of news for online channels (Bro, Hansen, \& Andersson, 2015; Wallace, 2013). Additionally, digital technology staff is hired that have become integral part of the editorial office (Kosterich, 2019). Robinson (2011) shows that staff with technological skills gained power within editorial hierarchies which increasingly isolates editors with traditional print-cultural mindsets. On structural level, some legacy news companies have formed company-wide technology units led by a chief technology officer (Lischka, 2019b), which has its seeds in the information technology industry.

Online-born news outlets often embrace technology as a core value. In Küng's (2015) multi-case study of successful news organizations, the pure-players Quartz, BuzzFeed, and Vice stress the advantages of being a first- or early-mover when it comes to technology adoption. Recently, news organizations are found to adopt a never-ending stream of "shiny new things" and to become exhausted by the adoption of various new technologies, overlooking to strategically integrate these technologies (Küng, 2017). This technology adoption process suggests that managerial logics temporarily subordinate tech logics. 
The literature review draws on recent digital journalism research and develops an overview about how competing logics are negotiated. As institutional logics provide individuals with a vocabulary, these negotiations found in various sources of digital journalism research should be represented in narrations on a micro level. Therefore, the following research question is asked.

How do journalists narratively negotiate professional, market, managerial, and tech logics?

\section{Method}

\section{Material}

The case study analyses negotiation vocabulary in texts about the future of journalism written by journalism experts: The NiemanLab of the Harvard University has invited "the smartest people in journalism" every year to share their predictions for journalism for the coming year. Ruotsalainen (2018) argues that the NiemanLab predictions are diverse and rich because the experts can express their view on the future of journalism freely without predefined questions. Thus, the material is nonresponsive to the present research goal of identifying negotiation strategies for competing institutional logics in journalism.

The experts come from diverse backgrounds at digital and legacy media organizations as well as academia. They are journalists, media analysts, entrepreneurs, CEOs, and researchers. Job titles cover a wide range (and could be subject to an individual analysis), including, for instance, front-end designer, data journalist, design director, product manager, chief innovation officer, vice president of business development, technology reporter, and chief technology officer. Most of the experts work in U.S. media companies and a small share in other regions such as Latin American, Asia, and Europe. The predictions are therefore based on a purposive sample following a reputational case sampling (Teddlie \& 
Yu, 2007), in which mostly U.S. journalism experts are deliberatively selected for the information they can provide about future developments in journalism.

The predictions of all experts are published on a website showing author, headline, and lead text of each prediction. The full article for an individual prediction is accessible through clicking. The content analysis focuses on the headline and lead text for analysis and involves the full article only if the statement is not clear from headline and lead.

The number of practitioners writing the short and popularized texts increases every year for $23 \%$ on average, potentially including a wider range of visions. For 2014, 52 experts made a prediction, for 2015, 65 experts, for 2016, 106 experts, for 2017, 140 experts, for 2018, 176 experts, and for 2019205 experts expressed their view. This case study selects the responses from 2014 until 2018, comprising a 6-year period of predictions summing up to 744 individual predictions.

When relying on narrations, this analysis focuses on reflections of journalists about their profession. These reflections are nurtured by the practice of journalism, filtered by what journalists want to do, and interpreted against the normative expectations towards journalism (Hanitzsch \& Vos, 2017). That is, narratives represent a conglomeration of various dimensions of journalistic role conceptions and role performance. These are depicted from the experience of each individual expert, who presents their views on a popular and prestigious outlet to their peers.

\section{Context}

The observation period is marked with two major external developments relevant for journalism. First, it covers Trump's election campaign and presidency. Since then, legacy news organizations are accused of being fake news outlets and "enemy of the people" by Trump, which represents a major challenge for the legitimacy of journalism (Lischka, 2019a). 
Second, digital platforms are increasingly problematic for news organizations since they obtain a major share of advertising revenue and are new, powerful gatekeepers of information distribution, including the distribution of misinformation during the 2016 U.S. presidential election campaign (Nielsen \& Ganter, 2017). Both developments are present in the NiemanLab predictions.

\section{Analysis}

The data is qualitatively analyzed using grounded theory procedures, which are useful for understanding negotiation; events causing disorder will cause ongoing ordering attempts, enhancing negotiation processes (Strauss, 1993). For journalism, such events include digitization, Trump's fake news allegations, and the spread of disinformation online. The NiemanLab statements are developed against this background and aim at sustainably enhancing journalism.

First, the grounded-theory question "What is this statement a matter of?" (e.g., Glaser, 1992) is asked while close reading of each statement. The coding framework is predefined as professional, market, managerial, and tech logics, following Nicolini et al. (2016) and Russell (2017). When addressing normative role performance and journalism's role for society (Deuze, 2005; Hanitzsch \& Vos, 2017), statements are categorized as narrating professional logics. When discussing advertisers or audiences according to journalism's two target markets, statements are categorized as representing market logics. Thereby, audience orientation overlaps between professional and market logics. For example, the 2014 statement, "Reducing the cognitive burden of news. We need them to tell important stories from a perspective about which the audience cares and in a manner which enraptures them," refers to audiences and to the role of journalism as interpreter. It is coded as professional logic because the overall theme is a call to adapt professional roles. When matters of 
organizational change or production are tackled, statements are classified as managerial logics. When referring to digital technology, its applications, and its providers such as digital platforms, statements are coded as discussing tech logics. Going through the statements, coding was constantly compared to previous codes until the no more changes were made to the categorization, indicating separate categories and theoretical saturation (Holton, 2011).

Overall, two thirds of the statements are classified to one logic. The remaining statements address specific topics (e.g., local journalism, citizen journalism, race equality) or were very general, for instance, “Thanks, \#fakenews. Journalism is often at its best during periods of genuine turmoil or uncertainty." Exemplary statements for each year are summarized in Table 1.

Second, memos are written, which are notes about the conceptual connections between categories (Holton, 2011) and diagrams sketched to visualize the connections (Bex Lempert, 2011). Diagram sketching and memo writing started in parallel with the coding process and focused on the negotiating strategies regarding institutional logics developed by Pratt and Foreman (2000). Due to coding the statements repeatedly year-by-year, diagrams and memos about the connections represent developments over time. Based on diagrams and memos, each logic is compared to Pratt and Foreman's (2000) classification of negotiation strategies of competing logics.

\section{Findings}

\section{Professional logics}

Constant themes throughout the observation period are active roles of journalists and journalism's responsibility for the public (see Table 1). While in 2014, persistently placing topics on the public agenda is regarded as important, to interpret such topics is relevant in 2015, and to campaign topics in 2016. This indicates a climax from agenda setting to 
journalism as activism. For 2017 and 2018, the focus is on educating the public to recognize what is fact and fake considering misinformation distribution online. An increasing focus on active professional role conceptions is depicted as a way forward. The discourse concerning professional logics suggests that journalism continuously needs to develop additional benefits and embrace new functions, so journalism remains relevant for the public. Against the background of losing legitimacy and disinformation distribution online, journalists hold their responsibility for a well-informed public high.

For the 2019 predictions, the conclusion is drawn that the potential of journalism regarding social impact is not exploited. It is criticized that the innovative capacity in journalism did not sufficiently enhance positive effects of journalism for society. Managerial aspects of technology adoption are expected to enrich the progress of professional logics. That is, market, managerial, and tech logics are not depicted as competitors but as supporters of professional logics. Hence, professional logics are normatively presented as superior to the other logics. Yet, the practice of journalism does not comply with this normative requirement. Thus, the ideal conception of the relation between professional and other logics is a nurturing of market, managerial, and tech logics, which in turn enhance professional logics (see Figure 1).

[Figure 1 about here]

\section{Market logics}

Reader orientation is a steady major theme in the predictions; however, reader commodification is only indirectly related. Data on user-behavior to develop personalized news products as well as integrating the reader into the news making process are discussed. Thereby, readers are conceptualized as users who leave data traces that allow "deep audience insights." These insights help to satisfy readers' needs on an individual level. As a desirable 
goal, a truly reader-driven organization is advocated. From 2014 to 2018, the means is user data analysis. In 2019, predictions turn to more strongly integrating the opinions of readers. Overall, the possibilities of data-driven reader orientation are applied to the fullest and customer demands can increasingly shape the news. The 2017 market logics statement in Table 1 stands out as it criticizes the quantification of readers using myopic audience metrics. This statement indicates that the technologic possibilities to measure user behavior is ineffective. Thus, the application of technology has not sufficiently enhanced reader orientation.

Yet, the maximization of readers, which is central to journalism market logics, is no explicit goal discussed by the journalists, but personalization of news and an increase of relevance of news for readers are pursued. Thus, journalists do not discuss "pure" market logics but user orientation in respect of professional logics.

\section{Managerial logics}

Managerial issues concern diverse aspects regarding organizational change and learning, including newsroom convergence, internal and external collaboration, cultural change, changes of procedures, learning new skills, integrating of new job roles, and effective exploitation of capacities. These changes are induced by new technology, which poses challenges to news organizations if ignored. The predictions suggest that news organizations are overwhelmed with applying new technology. Reactions on managerial level are described as lagging behind developments in digital technology and user behavior. In 2019 , the ability to strategically chose to adopt useful technology among "all shiny new things" (Küng, 2017) is demanded. That is, constant technology innovation loses its relevance and desirability. Instead, the discussion about managerial tasks is guided by the ideal of improving the industry to keep "great journalism alive." 
Thus, managerial logics are determined by tech logics of constant innovation and techno-utopian views in the beginning of the observation period and are renegotiated by professional logics.

\section{Tech logics}

Expressions about technology refer to two themes: technology as an enabler of journalism and the double-edged role of digital publishers. Regarding technology as enabler, it is implemented to reach the normative goals of professional logics. Technology is described as assisting and thereby improving the work of journalists. These narratives represent techno-utopian views since present problems are solved through technology (Russell, 2017), which serves society. Moreover, new professional groups in editorial offices who are mission-driven technologists represent an aggregation of competing professional and tech logics through linking them according to Pratt and Foreman (2000). News nerds therefore represent the synergy between professional and tech logics.

While digital platforms were depicted as agents for change, digital platforms are identified as "part of the problem" in 2019. For 2016, digital platforms are described as determining journalistic work in a way that innovations are increased. However, that digital platforms determine news distribution and are therefore powerful agents is acknowledged as well. That is, journalists have the capacity to react to features of digital platforms instead of remaining active agents. In 2019, journalism is regarded to have the responsibility to become active and desisting from being "Facebook's enabler." Thus, journalism resides in a war of independence from digital platforms.

Overall, the implementation of technology is supposed to enhance journalism's normative goals. Digital technology is adopted and integrated into news production. 
However, when technology does not enhance journalism, technology use is requested to discontinue. Thus, tech logics are negotiated with more dominant professional logics.

[Table 1 about here]

\section{Conclusions}

This study reviews the negotiation of competing institutional logics in news organizations that are active in multiple institutional domains. Institutional logics are conceptualized as socially constructed, normative guides that are reflected in vocabularies of organizational actors. This study argues that contemporary changes in journalism can be grasped through the negotiation of institutional logics. It shows how a set of four institutional logics, i.e., professional, market, managerial, and tech logics, interact with each other and shape the field of journalism.

The present findings imply that an active institutional negotiation process is in place in journalism. The negotiation indicates synergy building processes between logics, while professional logics remain dominant as a moral compass for journalists. Tech logics are negotiated against the background of professional logics and become professional-induced tech logics. Thereby, tech logics are expected to enhance managerial and market logics. News organizations apply technology either in compliance with professional logics or discuss technology application critically against the background of fulfilling normative goals. Thus, when tech logics oppose professional logics, it sets the stage for intense internal conflict, which is indicated by critical discussions of journalists regarding the role of audience metrics or social-media algorithm logics for news making. Changes on market, management, and tech domains are judged on their capacity to fulfil professional goals. Professional logics function as a protective shield for journalism's legitimacy and sustainability as well as the point of view from which potentially competing domains are 
evaluated. These traditional logics shape how journalism responds to new logics. However, professional logics do not remain static, but tech logics trigger an advancement of professional logics.

Comparing journalism's negotiation of competing logics to Pratt and Foreman's (2000) strategies for competing identities, two negotiation modes prevail. One mode is the aggregation of competing logics through linking them to each other. One example represents new editorial staff such as news nerds and bridge people who link professional and tech logics. A second example is the combination of managerial and tech logics in the beginning of the observation period. Since the synergetic aggregation of both leads to exhaustive innovation, a state that also Küng (2017) observed, professional logics are used to weaken the role of tech logics and create a hierarchy of logics. Thus, institutional logics in journalism remain high in plurality and high in synergy, according to Pratt and Foreman's (2000) model.

With a growing complexity of institutional logics, the requirements for the management of news organizations increase. Managers of news organizations have to develop a strong and unique stance regarding competing logics and the dominance of professional logics. Based on this stance, employees can be socialized into the unique logic set of the organization.

Organizations that negotiate competing logics are regarded as future sustainable organizations because they develop sustainable business models that are competitive and create positive social change (Haigh \& Hoffman, 2012). This detection implies that a discussion about competing logics, which is vivid in news organizations, is beneficial for the organization as well as for society. That is, debates in journalism about their role as well as the role of digital platforms may help to manage competing logics in an optimum way for journalism and society. 
The present analysis draws a rough picture about the negotiation of competing logics in journalism based on narrations of experts in the fields who are predominantly newsroom practitioners from the U.S. Future research may further observe the negotiation of competing logics in various fields within journalism, i.e., local journalism, non-profit journalism or market-oriented journalism. Moreover, future research can find ways to test how beneficial, if at all, the active negotiation of competing logics is for the news industry and society. Finally, an in-depth analysis of the role of the new tech positions in editorial offices such as news nerds is informative regarding the negotiation between professional and tech logics.

\section{References}

Achtenhagen, L. (2015). Understanding Entrepreneurship in Traditional Media. Journal of Media Business Studies, 5(1), 123-142.

https://doi.org/10.1080/16522354.2008.11073463

Achtenhagen, L., \& Raviola, E. (2009). Balancing tensions during convergence: Duality management in a newspaper company. International Journal on Media Management, 11(1), 32-41. https://doi.org/10.1080/14241270802518505

Alvesson, M., Hallett, T., \& Spicer, A. (2019). Uninhibited Institutionalisms. Journal of Management Inquiry, 51, 105649261882277. https://doi.org/10.1177/1056492618822777

Andersson, U., \& Wiik, J. (2013). Journalism meets management. Journalism Practice, 7(6), 705-719. https://doi.org/10.1080/17512786.2013.790612

Beam, R. A. (2003). Content differences between daily newspapers with strong and weak market orientations. Journalism \& Mass Communication Quarterly, 80(2), 368-390. https://doi.org/10.1177/107769900308000209 
Bex Lempert, L. (2011). Asking Questions of the Data: Memo Writing in the Grounded Theory Tradition. In A. Bryant \& K. Charmaz (Eds.), The SAGE handbook of grounded theory (pp. 254-264). Los Angeles, Calif.: Sage Publ.

Brès, L., Raufflet, E., \& Boghossian, J. (2018). Pluralism in Organizations: Learning from Unconventional Forms of Organizations. International Journal of Management Reviews, 20(2), 364-386. https://doi.org/10.1111/ijmr.12136

Bro, P. (2018). Constructive journalism: Proponents, precedents, and principles. Journalism, 1-16. https://doi.org/10.1177/1464884918770523

Bro, P., Hansen, K. R., \& Andersson, R. (2015). Improving productivity in the newsroom? Deskilling, reskilling and multiskilling in the news media. Journalism Practice, 1-14. https://doi.org/10.1080/17512786.2015.1090883

Burrowes, C. P. (2011). Property, Power and Press Freedom: Emergence of the Fourth Estate, 1640-1789. Journalism \& Communication Monographs, 13(1), 2-66.

Carlson, M. (2016). Order versus access: News search engines and the challenge to traditional journalistic roles. Media, Culture \& Society, 29(6), 1014-1030. https://doi.org/10.1177/0163443707084346

Carlson, M., \& Usher, N. (2016). News startups as agents of innovation. Digital Journalism, 4(5), 563-581. https://doi.org/10.1080/21670811.2015.1076344

Cherubini, F., \& Nielsen, R. K. (2016). Editorial Analytics: How News Media Are Developing and Using Audience Data and Metrics. Retrieved from http://www.digitalnewsreport.org/publications/2016/editorial-analytics-2016/

Chua, S., \& Westlund, O. (2019). Audience-Centric Engagement, Collaboration Culture and Platform Counterbalancing: A Longitudinal Study of Ongoing Sensemaking of 
Emerging Technologies. Media and Communication, 7(1), 153.

https://doi.org/10.17645/mac.v7i1.1760

Coates Nee, R. (2014). Social responsibility theory and the digital nonprofits: Should the government aid online news startups? Journalism, 15(3), 326-343.

https://doi.org/10.1177/1464884913482553

Cornia, A., Sehl, A., \& Nielsen, R. K. (2018). ‘We no longer live in a time of separation': A comparative analysis of how editorial and commercial integration became a norm. Journalism: Theory, Practice \& Criticism, 22(2), 146488491877991. https://doi.org/10.1177/1464884918779919

Dennis, E. E., Warley, S., \& Sheridan, J. (2006). Doing Digital: An Assessment of the Top 25 U.S. Media Companies and their Digital Strategies. Journal of Media Business Studies, 3(1), 33-51. https://doi.org/10.1080/16522354.2006.11073438

Deuze, M. (2003). The web and its journalisms: Considering the consequences of different types of newsmedia online. New Media \& Society, 5(2), 203-230. https://doi.org/10.1177/1461444803005002004

Deuze, M. (2005). What is journalism? Professional identity and ideology of journalists reconsidered. Journalism, 6(4), 442-464. https://doi.org/10.1177/1464884905056815

DeVito, M. A. (2017). From editors to algorithms. Digital Journalism, 5(6), 753-773. https://doi.org/10.1080/21670811.2016.1178592

Duffy, A. (2019). Out of the shadows: The editor as a defining characteristic of journalism. Journalism, 11(3), 146488491982681. https://doi.org/10.1177/1464884919826818

Ekdale, B., Singer, J. B., Tully, M., \& Harmsen, S. (2015). Making Change: Diffusion of Technological, Relational, and Cultural Innovation in the Newsroom. Journalism \& 
Mass Communication Quarterly, 92(4), 938-958.

https://doi.org/10.1177/1077699015596337

Friedland, R., \& Alford, R. R. (1991). Bringing Society Back In: Symbols, Practices, and Institutional Contradictions. In W. W. Powell \& P. DiMaggio (Eds.), The new institutionalism in organizational analysis (pp. 232-263). Chicago: University of Chicago Press.

Gilbert, C. G. (2005). Unbundling the structure of inertia: Resource versus routine rigidity. Academy of Management Journal, 48(5), 741-763.

https://doi.org/10.5465/AMJ.2005.18803920

Gilbert, C. G. (2006). Change in the presence of residual fit: Can competing frames coexist? Organization Science, 17(1), 150-167. https://doi.org/10.1287/orsc.1050.0160

Glaser, B. G. (1992). Basics of Grounded theory analysis: emergences vs forcing. Mill Valley, CA: Sociology Press.

Greenwood, R., Raynard, M., Kodeih, F., Micelotta, E. R., \& Lounsbury, M. (2011). Institutional Complexity and Organizational Responses. The Academy of Management Annals, 5(1), 317-371. https://doi.org/10.5465/19416520.2011.590299

Haigh, N., \& Hoffman, A. J. (2012). Hybrid organizations. Organizational Dynamics, 41(2), 126-134. https://doi.org/10.1016/j.orgdyn.2012.01.006

Hamilton, J. T. (2004). All the news that's fit to sell: How the market transforms information into news. Princeton, NJ: Princeton University Press.

Hanitzsch, T. (2007). Deconstructing Journalism Culture: Toward a Universal Theory. Communication Theory, 17(4), 367-385. https://doi.org/10.1111/j.14682885.2007.00303.x 
Hanitzsch, T., \& Vos, T. P. (2017). Journalistic Roles and the Struggle Over Institutional Identity: The Discursive Constitution of Journalism. Communication Theory, 27(2), 115-135. https://doi.org/10.1111/comt.12112

Hanusch, F. (2017). Web analytics and the functional differentiation of journalism cultures: Individual, organizational and platform-specific influences on newswork. Information, Communication \& Society, 20(10), 1571-1586.

https://doi.org/10.1080/1369118X.2016.1241294

Healey, K., \& Woods, R. H. (2017). Processing Is Not Judgment, Storage Is Not Memory: A Critique of Silicon Valley's Moral Catechism. Journal of Media Ethics, 32(1), 2-15. https://doi.org/10.1080/23736992.2016.1258990

Hedman, U., \& Djerf-Pierre, M. (2013). The social journalist: Embracing the social media life or creating a new digital divide? Digital Journalism, 1(3), 368-385. https://doi.org/10.1080/21670811.2013.776804

Holton, J. A. (2011). The Coding Process and Its Challenges. In A. Bryant \& K. Charmaz (Eds.), The SAGE handbook of grounded theory (pp. 265-289). Los Angeles, Calif.: Sage Publ.

Jenkins, H. (2008). Convergence culture: Where old and new media collide. New York: New York University Press.

Kosterich, A. (2019). Managing news nerds: Strategizing about institutional change in the news industry. Journal of Media Business Studies, 78(2), 1-18. https://doi.org/10.1080/16522354.2019.1639890

Küng, L. (2015). Innovators in digital news. London, New York: I.B. Tauris \& Co. Ltd in association with the Reuters Institute for the Study of Journalism, University of Oxford. 
Küng, L. (2017). Going Digital: A Roadmap for Organisational Transformation. Retrieved from https://reutersinstitute.politics.ox.ac.uk/our-research/going-digital-roadmaporganisational-transformation

Larrondo, A., Domingo, D., Erdal, I. J., Masip, P., \& van den Bulck, H. (2016).

Opportunities and limitations of newsroom convergence. Journalism Studies, 17(3), 277-300. https://doi.org/10.1080/1461670X.2014.977611

Lischka, J. A. (2015). How structural multi-platform newsroom features and innovative values alter journalistic cross-channel and cross-sectional working procedures. Journal of Media Business Studies, 12(1), 7-28.

https://doi.org/10.1080/16522354.2015.1027114

Lischka, J. A. (2018). Logics in Social Media News Making: How social media editors marry the Facebook logic with journalistic standards. Journalism, Advance online publication. https://doi.org/10.1177/1464884918788472

Lischka, J. A. (2019a). A Badge of Honor? How The New York Times Discredits President Trump's Fake News Accusations. Journalism Studies, 20(2), 287-304. https://doi.org/10.1080/1461670X.2017.1375385

Lischka, J. A. (2019b). Strategic renewal during technology change: Tracking the digital journey of legacy news companies. Journal of Media Business Studies, 20(2), 1-20. https://doi.org/10.1080/16522354.2019.1635349

Lowrey, W., \& Erzikova, E. (2014). Shifting institutional orders and responses to technological disruption among local journalists in Russia and the U.S. International Communication Gazette, 76(7), 552-574. 
McChesney, R. W. (2000). Rich media, poor democracy: Communication politics in dubious times (Publ. in paperback). New York NY: The New Press.

McManus, J. H. (1992a). Serving the public and serving the market: A conflict of interest? Journal of Mass Media Ethics, 7(4), 196-208. https://doi.org/10.1207/s15327728jmme0704_1

McManus, J. H. (1992b). What kind of commodity is news? Communication Research, 19(6), 787-805. https://doi.org/10.1177/009365092019006007

McManus, J. H. (2009). The commercialization of news. In K. Wahl-Jorgensen \& T. Hanitzsch (Eds.), The handbook of journalism studies (pp. 218-235). New York: Routledge.

Møller Hartley, J. (2013). The online journalist between ideals and audiences: Towards a (more) audience-driven and source-detached journalism? Journalism Practice, 7(5), 572-587. https://doi.org/10.1080/17512786.2012.755386

Nee Coates, R. (2013). Creative Destruction: An Exploratory Study of How Digitally Native News Nonprofits Are Innovating Online Journalism Practices. International Journal on Media Management, 15(1), 3-22. https://doi.org/10.1080/14241277.2012.732153

Nelson, J. L., \& Tandoc Jr., E. C. (2018). Doing "Well” or Doing "Good": What Audience Analytics Reveal About Journalism's Competing Goals. Journalism Studies, 5(1), 1-17. https://doi.org/10.1080/1461670X.2018.1547122

Neuberger, C., Langenohl, S., \& Nuernbergk, C. (2014). Social Media und Journalismus. LfM-Dokumentation: Vol. 50. Düsseldorf: Landesanst. für Medien Nordrhein-Westfalen (LfM). 
Nicolini, D., Delmestri, G., Goodrick, E., Reay, T., Lindberg, K., \& Adolfsson, P. (2016). Look What's Back! Institutional Complexity, Reversibility and the Knotting of Logics. British Journal of Management, 27(2), 228-248. https://doi.org/10.1111/14678551.12156

Nielsen, R. K., \& Ganter, S. A. (2017). Dealing with digital intermediaries: A case study of the relations between publishers and platforms. New Media \& Society, 20(4), 1600 1617. https://doi.org/10.1177/1461444817701318

Pache, A.-C., \& Santos, F. (2013). Inside the Hybrid Organization: Selective Coupling as a Response to Competing Institutional Logics. Academy of Management Journal, 56(4), 972-1001. https://doi.org/10.5465/amj.2011.0405

Peters, C., \& Carlson, M. (2018). Conceptualizing change in journalism studies: Why change at all? Journalism: Theory, Practice \& Criticism, 146488491876067. https://doi.org/10.1177/1464884918760674

Picard, R. G. (2003). Cash cows or entrecôte: Publishing companies and disruptive technologies. Trends in Communication, 11(2), 127. https://doi.org/10.1207/S15427439TC1102_04

Picard, R. G. (2010). A business perspective on challenges facing journalism. In D. A. L. Levy \& R. K. Nielsen (Eds.), The changing business of journalism and its implications for democracy (pp. 17-24). Oxford: University of Oxford, Reuters Institute for the Study of Journalism.

Ponte, D., Pesci, C., \& Camussone, P. F. (2017). Between mission and revenue: Measuring performance in a hybrid organization. Managerial Auditing Journal, 32(2), 196-214. https://doi.org/10.1108/MAJ-11-2015-1276 
Pratt, M. G., \& Foreman, P. O. (2000). Classifying Managerial Responses to Multiple Organizational Identities. Academy of Management Review, 25(1), 18-42. https://doi.org/10.5465/amr.2000.2791601

Raviola, E., \& Hartmann, B. (2015). Business Perspectives on Work in News Organizations. Journal of Media Business Studies, 6(1), 7-36. https://doi.org/10.1080/16522354.2009.11073477

Robinson, S. (2011). Convergence crises: News work and news space in the digitally transforming newsroom. Journal of Communication, 61(6), 1122-1141. https://doi.org/10.1111/j.1460-2466.2011.01603.x

Ruotsalainen, J. (2018). Scanning the shape of journalism-Emerging trends, changing culture? Futures, 104, 14-24. https://doi.org/10.1016/j.futures.2018.06.011

Russell, F. M. (2017). The New Gatekeepers: An Institutional-level View of Silicon Valley and the Disruption of Journalism. Journalism Studies, 7(2), 1-18. https://doi.org/10.1080/1461670X.2017.1412806

Ryfe, D. M. (2009). Broader and deeper: A study of newsroom culture in a time of change. Journalism, 10(2), 197-216. https://doi.org/10.1177/1464884908100601

Scacco, J., Curry, A. L., \& Stroud, N. J. (2015). Digital divisions: Organizational gatekeeping practices in the context of online news. \#ISOJ, 5(1), 106-123. Retrieved from https://isojjournal.wordpress.com/2015/04/15/digital-divisions-organizationalgatekeeping-practices-in-the-context-of-online-news/

Schudson, M. (1989). The Sociology of News Production. Media, Culture \& Society, 11(3), 263-282. 
Schultz, J. (1998). Reviving the fourth estate: Democracy, accountability, and the media. Reshaping Australian institutions. Cambridge: Cambridge University Press. Retrieved from https://doi.org/10.1017/CBO9780511597138

Schultze, Q. J. (2004). Habits of the high-tech heart: Living virtuously in the information age. Grand Rapids, Mich.: Baker Books.

Singer, J. B. (2003). Who are these guys? The online challenge to the notion of journalistic professionalism. Journalism, 4, 139-163. https://doi.org/10.1177/146488490342001

Strauss, A. L. (1993). Continual permutations of action. New York: Aldine de Gruyter.

Tandoc, E. C., \& Ferrucci, P. (2014). A tale of two newsrooms: How market orientation influences web analytics use. Retrieved from http://www.academia.edu/8264434/A_tale_of_two_newsrooms_How_market_orientatio n_influences_web_analytics_use

Tandoc, E. C., \& Foo, C. Y. W. (2017). Here's What BuzzFeed Journalists Think of Their Journalism. Digital Journalism, 16(2), 1-17. https://doi.org/10.1080/21670811.2017.1332956

Teddlie, C., \& Yu, F. (2007). Mixed Methods Sampling. Journal of Mixed Methods Research, 1(1), 77-100. https://doi.org/10.1177/2345678906292430

Tewksbury, D. (2005). The seeds of audience fragmentation: Specialization in the use of online news sites. Journal of Broadcasting \& Electronic Media, 49(3), 332-348. https://doi.org/10.1207/s15506878jobem4903_5

Thornton, P. H., Ocasio, W., \& Lounsbury, M. (2012). The institutional logics perspective: A new approach to culture, structure, and process (1. publ). 
Vos, T. P., \& Singer, J. B. (2016). Media Discourse About Entrepreneurial Journalism. Journalism Practice, 10(2), 143-159. https://doi.org/10.1080/17512786.2015.1124730

Waeger, D., \& Weber, K. (2019). Institutional Complexity and Organizational Change: An Open Polity Perspective. Academy of Management Review, 44(2), 336-359. https://doi.org/10.5465/amr.2014.0405

Wagemans, A., Witschge, T., \& Deuze, M. (2016). Ideology as Resource in Entrepreneurial Journalism: The French online news startup Mediapart. Journalism Practice, 10(2), 160-177. https://doi.org/10.1080/17512786.2015.1124732

Wagemans, A., Witschge, T., \& Harbers, F. (2018). Impact as driving force of journalistic and social change. Journalism: Theory, Practice \& Criticism, 146488491877053. https://doi.org/10.1177/1464884918770538

Wallace, J. (2018). Modelling Contemporary Gatekeeping. Digital Journalism, 6(3), 274293. https://doi.org/10.1080/21670811.2017.1343648

Wallace, S. (2013). The complexities of convergence: Multiskilled journalists working in BBC regional multimedia newsrooms. International Communication Gazette, 75(1), 99-117. https://doi.org/10.1177/1748048512461764

Wasike, B. S. (2013). Framing news in 140 characters: How social media editors frame the news and interact with audiences via Twitter. Global Media Journal: Canadian Edition, $6(1), 5-23$.

Webster, J. G., \& Ksiazek, T. B. (2012). The dynamics of audience fragmentation: Public attention in an age of digital media. Journal of Communication, 62(1), 39-56. https://doi.org/10.1111/j.1460-2466.2011.01616.x 
Welbers, K., van Atteveldt, W., Kleinnijenhuis, J., Ruigrok, N., \& Schaper, J. (2016).

News selection criteria in the digital age: Professional norms versus online audience metrics. Journalism, 17(8), 1037-1053. https://doi.org/10.1177/1464884915595474

Willnat, L., \& Weaver, D. H. (2018). Social Media and U.S. Journalists. Digital Journalism, 6(7), 889-909. https://doi.org/10.1080/21670811.2018.1495570

$\mathrm{Wu}, \mathrm{T}$. (2016). The attention merchants: The epic scramble to get inside our heads (First edition). A Borzoi book. New York: Alfred A. Knopf.

Zamith, R. (2018). Quantified Audiences in News Production. Digital Journalism, 6(4), 418-435. https://doi.org/10.1080/21670811.2018.1444999

Zuboff, S. (2019). The age of surveillance capitalism: The fight for the future at the new frontier of power. London: Profile Books. 
Accepted manuscript. Please do not cite this version. Final version has been published and is available as:

Lischka, J. A. (2019). Fluid institutional logics in digital journalism. Journal of Media Business Studies, 5(1), 1-19. https://doi.org/10.1080/16522354.2019.1699764

Table 1: Exemplary statements about narrations of institutional logics

Logics

$\begin{array}{lll}\text { Professional } & \text { Manket } & \text { Tech }\end{array}$

2014

If journalism is to matter,
we can't just raise big

topics. We have to spread

2014 will be when

$[\mathrm{N}]$ ews nerds - developers

them, and then sustain

newsrooms apply what they coding in the public interest

them.

learned more broadly, to within media - are an

their whole organization. essential part of quality

Dominant

Active disseminator

Reader orientation

Organizational adoption

reporting.

theme

2015

[I]n the knowledge-first era I expect more of your

[T]hey're all going through For those of us with one

journalists face a new

colleagues to care about

huge cultural and strategic

foot in the print world and

mandate - getting it to

user paths and actions.

changes.

the other online, we need

make sense.

new systems that enable us 
to write once, run

anywhere, and move fast.

Dominant Interpreter User analysis

\section{theme}

2016

Dominant

theme
Activism

\section{[T]ake a stand for core \\ Pages look back on the}

liberties like free expression reader, seeing to a finer

— and then be leaders in

resolution the moments of

the campaign to save or restore them. the reading experience $[\ldots]$ coming year will see us and dynamically adjust.
Organizational change do on print Page 1 designs.

\section{Tech as work assistance}

\section{change}

$[\mathrm{M}]$ any newsrooms $\quad$ Now that Facebook has

(finally!) ditched the Page 1 introduced live video $[. .$.$] ,$ we'll see an explosion of live reporting, talk shows, and all kinds of

experiments.

User experience
Tech as agent for change 
We need to vaccinate the

The industry is running on

public with real journalism: metrics that serve no one

[...] what should be

well, but we continue

considered a fact and why. chugging along because we all equally accept the lie. from them.

on beating your competitor and more focus on learning

Think about how much

faster the industry would

The combination of AI and journalism will contribute

to a more informed and

efficient society by enabling journalists to conduct deep

analysis, uncover

corruption, and hold people and institutions

accountable.

\section{Educator}

theme

2018

Having been called

'enemies of the people'

[...], reporters are starting

to recognize the importance
Quality over quantification

By leveraging design-

thinking principles and deep

audience insights, we can

better understand our

\section{Tech as enabler for}

normative goals

we develop the

Tech workers turn to

journalism [because]

[t]hey're hungry for

something mission-driven 
Accepted manuscript. Please do not cite this version. Final version has been published and is available as:

Lischka, J. A. (2019). Fluid institutional logics in digital journalism. Journal of Media Business Studies, 5(1), 1-19. https://doi.org/10.1080/16522354.2019.1699764

$\begin{array}{lll}\text { of }[\ldots] \text { how they work to } & \text { readers on an individual } & \text { and facilitate effective } \\ \text { uncover wrongdoing and } & \text { level. } & \text { collaboration. }\end{array}$

check facts.

\section{Dominant}

Watchdog

theme

2019

Dominant

Impact

\section{Granular user orientation}

Over the years, journalists

have innovated narrowly,

focusing on how stories

look rather than what

journalism can do.

theme

journalist that works there

concerns of their readers.
To really be a reader-driven Hunting for a valid, data-

organization, every

should be open to the

knowledge, ideas, and

Reader orientation alive.

tested reason to drop a

promising idea reserves

their team's time for work

that makes money and

keeps great journalism

Change for normative goals

\section{Tech for normative goals}

Publishers come to terms

with being Facebook's enablers.

Note. Statements from NiemanLab Predictions for Journalism 2014 - 2019. 